Baumann 法によりえた。

cis-[1]: mp $144.5 \sim 145.5^{\circ} \mathrm{C}$ (アセトンーエーテル) (交献値 ${ }^{21)}$ $\left.145^{\circ} \mathrm{C}\right)$, 収染 $90 \%$ 。

分析值 C $60.92 \%, \mathrm{H} 9.93 \%, \mathrm{~N} 8.61 \%$ $\mathrm{C}_{8} \mathrm{H}_{15} \mathrm{NO}_{2}$ としての

計算值 C $61.12 \%, \mathrm{H} 9.62 \% ， \mathrm{~N} \mathrm{8.91 \%}$ cis-〔2]: $\mathrm{mp} 86 \sim 87^{\circ} \mathrm{C}$ (ベンセンーエーテル), 収率 65\%。

分析值 C $63.00 \%, \mathrm{H} 10.20 \%, \mathrm{~N} 8.15 \%$ $\mathrm{C}_{9} \mathrm{H}_{17} \mathrm{NO}_{2}$ としての

計算值 C $63.13 \% ， \mathrm{H} 10.00 \% ， \mathrm{~N} \mathrm{8.18 \%}$ cis-[3]: $\mathrm{mp} 96 \sim 97^{\circ} \mathrm{C}($ エーテル), 收率 $80 \%$ 。

分析值 C $64.99 \%, \mathrm{H} 10.40 \%, \mathrm{~N} 7.49 \%$

$\mathrm{C}_{10} \mathrm{H}_{19} \mathrm{NO}_{2}$ としての

計算值 C $64.84 \% ， \mathrm{H} 10.34 \% ， \mathrm{~N} \mathrm{7.56 \%}$ cis-[4]: $\mathrm{mp} 43 \sim 44^{\circ} \mathrm{C}$ (石油エーテル), 収菜 $62 \%$ 。

分析值 C $73.02 \%, \mathrm{H} 8.71 \%, \mathrm{~N} 5.52 \%$

$\mathrm{C}_{15} \mathrm{H}_{21} \mathrm{NO}_{2}$ としての

計算值 C $72.84 \%, \mathrm{H} 8.56 \%$ ，N 5.66\%

3.1 .5 trans-〔2]と塩酸の反応生成物の立体配置: trans-[2] $100 \mathrm{mg}(0.6 \mathrm{mmol})$ を濃塩酸 $0.2 \mathrm{ml}(2 \mathrm{mmol})$ を含むジオキサン $3 \mathrm{~m} l$ に溶かし， 3 時間還流した。減圧で乾固し，残留物を $1 \%$ 塩酸と $90^{\circ} \mathrm{C}$ で 1 時間加熱した。減圧乾固し, 生成したアミノ

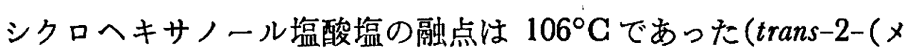
チルアミノ)シクロヘキサノール塩酸塩 は $\mathrm{mp} 114 \sim 115^{\circ} \mathrm{C}^{21)}$, cis-2-(メチルアミノ) シクロヘキノール塩酸塩は mp 204 205 ${ }^{\circ} \mathrm{G} 21$ である)。アセトンーエーテルから 1 回再結晶して, mp 116 ${ }^{\circ} \mathbf{G}$ となった。これは標品と融点降下を示さなかった。

粗製残留物に， $1 \%$ 水酸化ナトリウム水溶液 $10 \mathrm{ml}$ を加え,
エーテルで連続抽出(50 時間)，エーテルを留去したのちの 2(メチルアミノ) シクロヘキサノールを薄層クロマトグラフで検討 したところ，トランス体のスポットしかえられなかった(ワコー ゲル B10，1-ブタノール 6 : 酢酸 $3:$ 水 1 , 室温ではトランスの $R_{f} 0.45$, シスの $R_{f} 0.31$ でかなり明確に分離する)。

以上から，trans-[2]に対して塩酸による $\mathrm{N} \rightarrow \mathrm{O}$ アセチル転 位を行ない(加水分解して)，生成したアるノシクロヘキサノール の立体配置について，カルビニル炭素の反転は起こっていない。 trans-[4]に対して 同様に 調べたが，トランス体しかえられな かった。

\section{$3.2 p K_{a}$ の測定}

trans-〔 9 〕からえられる塩酸塩 (mp $172^{\circ} \mathrm{C}$ (文献値 ${ }^{21)} 174 \sim 175$ ${ }^{\circ} \mathrm{G}$ ), trans- $[10] \mathrm{N}-\mathrm{CH}_{3}, \mathrm{mp} 114 \sim 115^{\circ} \mathrm{G}$ (文献值 ${ }^{28)} 114 \sim 115^{\circ} \mathrm{G}$ ), $N-\mathrm{C}_{2} \mathrm{H}_{5}, \mathrm{mp} 154 \sim 155^{\circ} \mathrm{C}$ (文献值 ${ }^{24)} 155^{\circ} \mathrm{C}$ ))，および cis-[11] を用いて $15^{\circ} \mathrm{G}, 60 \%$ 水性ジオキサン中で, 電位差滴定により 求めた $p K_{a}$ 值を表 3 亿示す。

本文 2 の cis-O-アセチル-2-(エチルアミノ) シクロヘキサノー ル塩酸塭〔8]はつぎのようにしてえた。

cis-[3] $0.37 \mathrm{~g}$ をジオキサン $20 \mathrm{~m} l$ に溶かし, 濃塩酸 $0.2 \mathrm{~m} l$ を加え, 30 分還流し, 溶媒を留去, 残留物をアセトンーメタノー

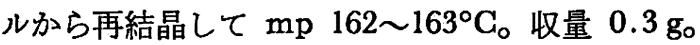

分析值 $\mathrm{C} 54.13 \%, \mathrm{H} 9.23 \%, \mathrm{~N} 6.67 \%$

$\mathrm{G}_{10} \mathrm{H}_{20} \mathrm{NO}_{2} \mathrm{Cl}$ としての

計算值 C $54: 17 \%$ ，H 9.09\%，N 6.32\%

誤差は \pm 0.02 以下である。

\section{3 速度の測定}

前報)と同じ。誤差は $k_{2}$ の值の $\pm 2 \%$ を越えない。

\title{
イソプレンと四塩化峞素との付加物の構造*1, $*_{2}$
}

（昭和 44 年 2 月 12 日受理）

\author{
田中順太郎・片桐 孝夫・山本健・高部 图彦*3
}

耐圧ガラスびん中で，金属塩およびフミンによるレドックス触媒を用いて，インプレンと四塩化炭系とのテロメル化反応を行な った。生成物を精密分留して，55\%の収率で， $n=1$ テロマー $\left(\mathrm{bp}_{5} 82 \sim 86^{\circ} \mathrm{G}\right)$ をえ，これをガスクロマトグラブにより分析し,4 種 の主生成物の存在することを確かめ, さらに分取して化学的方法と分光学的方法により，これらは 1,1,1,5-テトラクロル 3-メチ ルー3-ペンテンおよび 1,5,5,5-テトラクロル-3-メチル-2-ペンテンのそれぞれの幾何異性体であるととを確かめた。

\section{1 緒言}

テルペン化合物の合成を目的としたイソプレンのテロメル化反 応22の一環として本研究を行なった。

*1 この報交を “テロメル化反応によるテルペン類の 合成 (第 3 報)”とする.

*2 前報(第 2 報), 田中順太郎, 片桐孝夫, 竹下 徹, 日化, 89, 875(1968).

*3 Juntaro Tanaka, Takao Katagiri, Takeshi Yamamoto, Kunihiko TAKABE 静岡大学工学部合成化学科, 浜松市 城北
イソプレンとポリハロゲン化メタンとのラジカルテロメル化反 応に関しては，開始剤として有機過酸化物，放射線などを用いた イソプレンとトリクロルブロムメタンとの反応344, 四具化炭素と の反応5)，および最近のイソプレンに対するトリクロルブロムメ

1) 田中順太郎, 片桐孝夫, 竹下 徹, 日化, 89, 65(1968).

2）前報(第 2 報)，田中順太郎，片桐孝夫，竹下 徹，日化， $89,875(1968)$.

3) M. S. Kharash, U. S. P., 2, 468, 208(1949).

4) C. S. H. Ghen, E. F. Hosterman, J. Org. Chem., 28, 1585(1963).

5) G. Rabillond, Bull. Soc. Chim. France, 8, 2149(1965). 
タンと四塩化炭素との反応性に対する研究6)などがある。しかし いずれも生成する $n=1$ テロマーの構造に関して部細な検討はと されていない。

本研究は，触媒としてエチレンに関して比較的低分子量のテロ マーの生成が報告》 10)されている金属塩-アミン触媒によるイソ プレンと四塩化炭素との反応を行ない, 生成する $n=1$ テロマー に関して，新たな知見がえられたので報告する。

\section{2 実験}

\section{1 反応}

$200 \mathrm{ml}$ 耐圧ガラスびんにイソプレン $1 \mathrm{~mol}(68 \mathrm{~g})$, 四塩化炭 素 $0.5 \mathrm{~mol}(77 \mathrm{~g})$ を加光, 塭化銅 (II)-二水塩 $0.01 \mathrm{~mol}(1.7 \mathrm{~g})$, モノェタノールアミン $0.02 \mathrm{~mol}(1.2 \mathrm{~g})$ をアセトニトリル $1 \mathrm{~mol}$ (41 g )にそれぞれ溶解したものを加え公素置換し，120 $\mathrm{G} ， 8$ 時 間かきまぜて反応させた。反応終了後 $0.1 \mathrm{~N}$ 塩酸で洗浄して触媒 を除去し，つぎに減圧下で溶媒および未反応物を留去した。残留 物をさらに精密分留し, 無色透明な $n=1$ テロマー( bp $_{5}$ 82 86 ${ }^{\circ} \mathrm{C}$ )をえた。収量 $61 \mathrm{~g}$ ，四塩化炭素に関しての収率 $55 \%$ ，分子 量. 221 (計算值*4 221.9)，塩素含有量 $63.8 \%$ (計算値*4 $63.9 \%$ )。

\section{2 分 析}

$n=1$ テロマーは，おのおのガスクロマトグラフィー(GLC)を 用いて分取(ピーク 1〜4)し, 核磁気共鳴スペクトル (NMR), 赤 外吸収スペクトル(IR)，Shöniger 法による塩素定量 ${ }^{11) ， お よ ひ ゙ ~}$ ベンゼンを用いた凝固点降下法による分子量測定などの分析を行 なって構造を决定した。

\section{3 結果および考察}

\section{$3.1 n=1$ テロマー留分の GLC}

$n=1$ テロマー留分を GLG で分析し*5, えられたガスクロマ トグラムを図 1 に示した。主生成物は 4 成分(GLC\%：97)からな り，ピーク 1，2，3，4 の GLG 上での面積比は，およそ 60 :

$21: 7: 12$ であった。なお保持時間 4.2〜 5.8 分のところに幅広 くてはっきりと形を示さないピーク 5 および 6 が存在した。

\section{2 各ピークの構造}

GLG 分取によりえられた四つのテロマー（ピーク 1〜4，それ ぞれ I，I， II， IV とする)の構造に関して，IR，NMR を用い て検討した。

3.2.1 I(ピーク 1)の構造：ピーク 1 の分取物 I の分子量は 223 。塩素含有量 $63,9 \%$ で $n=1$ テロマー $\mathrm{C}_{6} \mathrm{H}_{8} \mathrm{Cl}_{4}$ としての計 算値(分子量 221.9 ; 塩素含有量 $63.9 \%$ ) とよく一致し, その IR は $708,758 \mathrm{~cm}^{-1}\left(-\mathrm{CCl}_{3}\right), 1255 \mathrm{~cm}^{-1}(=\mathrm{C}-\mathrm{C}-\mathrm{Cl}), 595 \mathrm{~cm}^{-1}(\mathrm{C}-$

6) I. B. Afanasév, I. B. Mamontoba, S. B. Prigoda, M. B. Levinshii, G. I. Samokhvalon, Zh. Org. Khim., 4, 776(1968).

7) 高橋 彰(昭和電工株式会社), 日特公, 18,389(1962).

8) M. Asscher, D. Vofsi, J. Chem. Soc., 1963, 1887.

9) M. Asscher, E. Levy, H. Rosin, D. Vofsi, Ind. Eng. Chem., Prod. Res. Develop., 2, 121(1963).

10) T. Asahara, J. Hirano, Bull. Japan Petrol. Inst., 6, 65(1964).

*4 以下計算值はすべて $\mathrm{C}_{6} \mathrm{H}_{8} \mathrm{Cl}_{4}$ としての值.

11) W. Shöniger, Micro Chim. Acta, 1955, 123.

*5 数種のカラムを試みたが本研究に使用したものがもっと も分蜼がよかった。

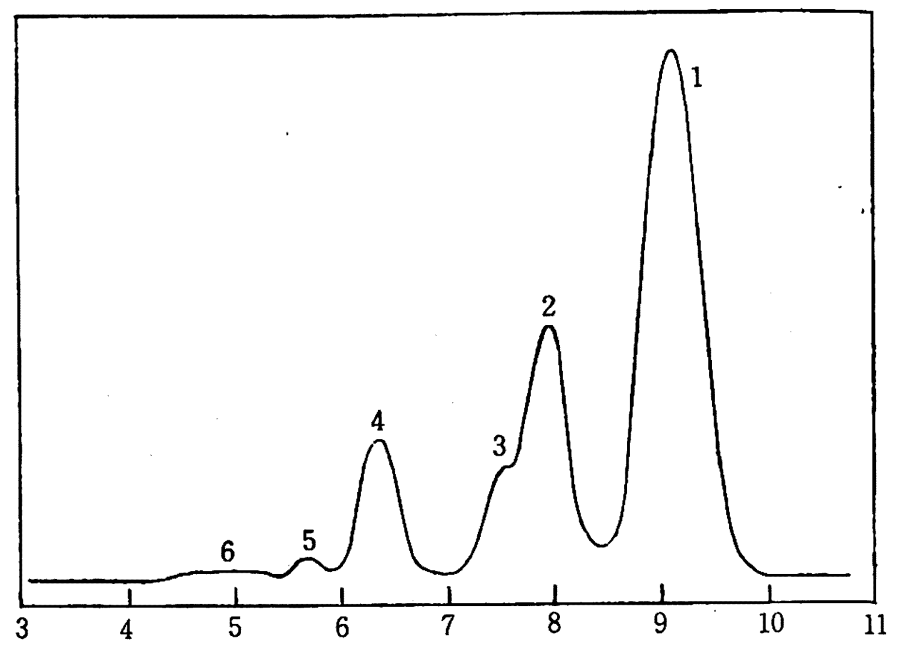

保持時間 ( $\mathrm{min})$

DEGA*6 15\%/ネオソルブ NC: $25 \mathrm{~m}$, $155^{\circ} \mathrm{C}, \mathrm{H}_{2}: 60 \mathrm{ml} / \mathrm{min}$

因 $1 n=1$ テロマー留分の GLC

$\mathrm{Cl})$ ，および $1650,806 \mathrm{~cm}^{-1}\left(\begin{array}{l}\mathrm{R}_{1} \\ \mathrm{R}_{2}\end{array} \mathrm{C}=\mathrm{C}<\mathrm{R}_{\mathrm{H}}\right)^{2}$ などの特性吸収を示 した。また NMR(図 2)においても，オレフィンプロトン領域に メチンプロトン(5.76 ppm(t ))の吸収が見られ，三置換二重結合の 存在を示した。したがってその構造式として[1]または[2]が考 えられる。いずれも二つのメチレンプロトン $\left(\mathrm{CCl}_{3} \mathrm{CH}_{2^{-}}, \mathrm{ClCH}_{2^{-}}\right)$<smiles>C/C=C\CCl</smiles>

1,4-付加物 [1]<smiles>C/C=C\C(Cl)C(Cl)(Cl)Cl</smiles>

4,1 -付加物 $[2]$
をもっているが，そのうちより低磁場側に吸収をもつメチレンプ ロトン $\left(\mathrm{ClCH}_{2}-\right)$ が，図 2 においてはメチンプロトンとカップリ ングして二重線に分裂しており，xチレンプロトン $\left(\mathrm{ClCH}_{2^{-}}\right)$が メチンプロトンに隣接していることを示している*8。すなわちI

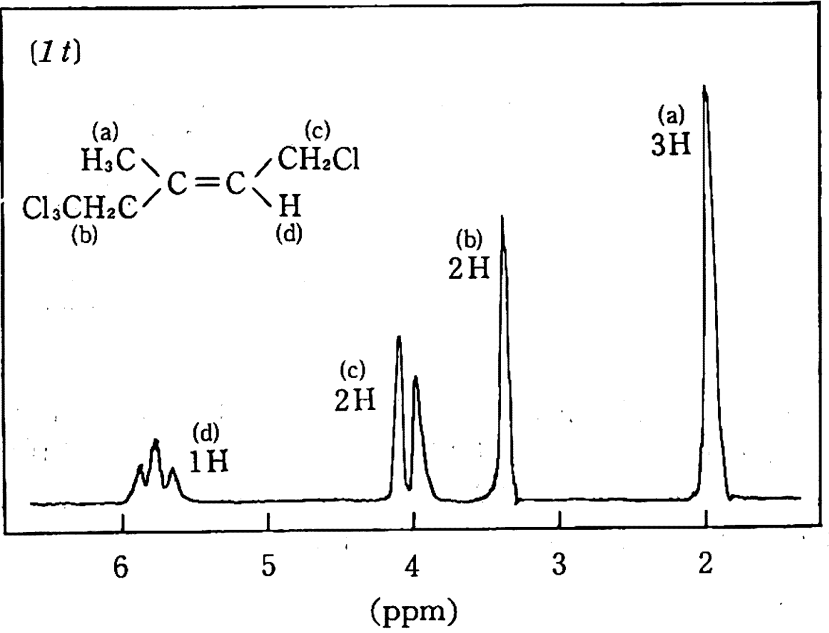

図 2.ピーク1( I )の NMR*?

*6 ジェチレングリコールーアジピン酸ポリエステル.

*7. $60 \mathrm{Mhz}, 32^{\circ} \mathrm{C}$ 四塩化炭䜿 $10 \%$ 溶液, 内部標焦 TMS.

*8 メチレンプロトンに関する Shoolery の加成則122におい: て，- $\mathrm{CF}_{3}$ の有効遮蔽定数は $-\mathrm{Cl}$ のそれに対して小さな

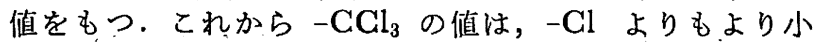
さな值をもつことは明らかである。ここで間題にしてい る化合物のメチレンにおいては，- $\mathrm{CCI}_{3}$ または- $\mathrm{Cl}$ の もう一方の側の有効遮蔽定数は同程度と見られるから， $-\mathrm{CCl}_{3}$ がついたメチレンが $-\mathrm{Cl}$ のついた方にくらべて より高磁場側にシグナルが見られる。

12) B. P. Dailey, J. N. Shoolery, J. Am. Chem. Soc., 77, 3977 (1955). 
(ピーク 1)は構造[1]を満足する。

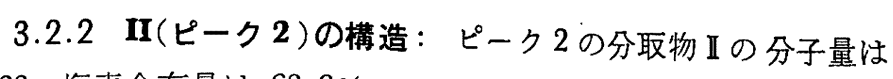
223 , 塩秦含有量は $63.8 \%$ でテロマー $\mathrm{C}_{8} \mathrm{H}_{8} \mathrm{Cl}_{4}$ としての計算値 (分子量 221.9, 塩素含有量 63.9\%) と一致し，その IR は 707, $772 \mathrm{~cm}^{-1}\left(-\mathrm{CGl}_{3}\right), \quad 1263 \mathrm{~cm}^{-1}(=\mathrm{C}-\mathrm{C}-\mathrm{Cl}), 609 \mathrm{~cm}^{-1}(\mathrm{C}-\mathrm{Cl})$, お

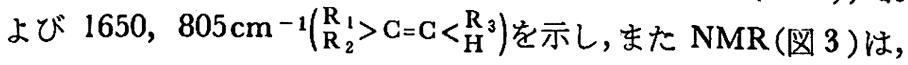
I とは逆にメチレンプロトン $\left(\mathrm{CCl}_{3} \mathrm{CH}_{2}-\right)$ が二重線に分裂してい る。したがって II（ピーク 2 )は橉造式〔 2 〕を満足する。

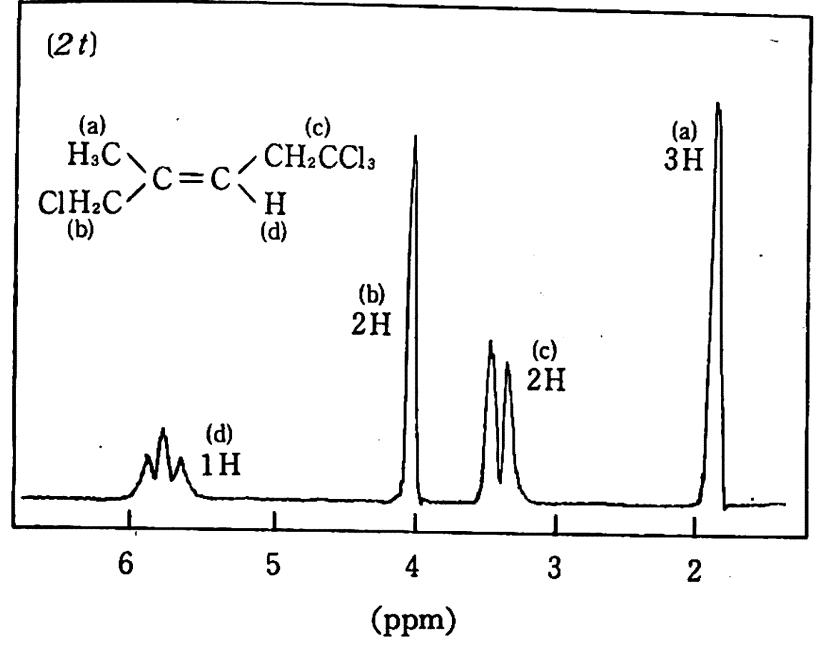

四 3 ピーク 2(II)の $\mathrm{NMR} * 7$

3.2.3 III (ピーク 3 )の構造：ピーク 3 はピーク 2 との分離が 現在のところ不可能であり，量も少なく，純粋にえることができ なかったので，ピーク 2 との混合物のまま分析を行なった。その NMR を図 4 に示した。これは GLC からもわかるように，I (ピーク 2 )と吕（ピーク 3 )の混合物であるから，II帰属される 部分を除いて作罒すれば， IIスペクトルと考えられる斜線で示 した図がえられる。これからピーク 3 を示す化合物 IIは，I と同 様に一重線のメチレンプロトン $\left(\mathrm{CCl}_{3} \mathrm{CH}_{2}-\right)$ ，および二重線に分 裂したメチレンプロトン $\left(\mathrm{ClCH}_{2}-\right)$ を示し, I と同じ平面棈造式 〔1〕を满足する。

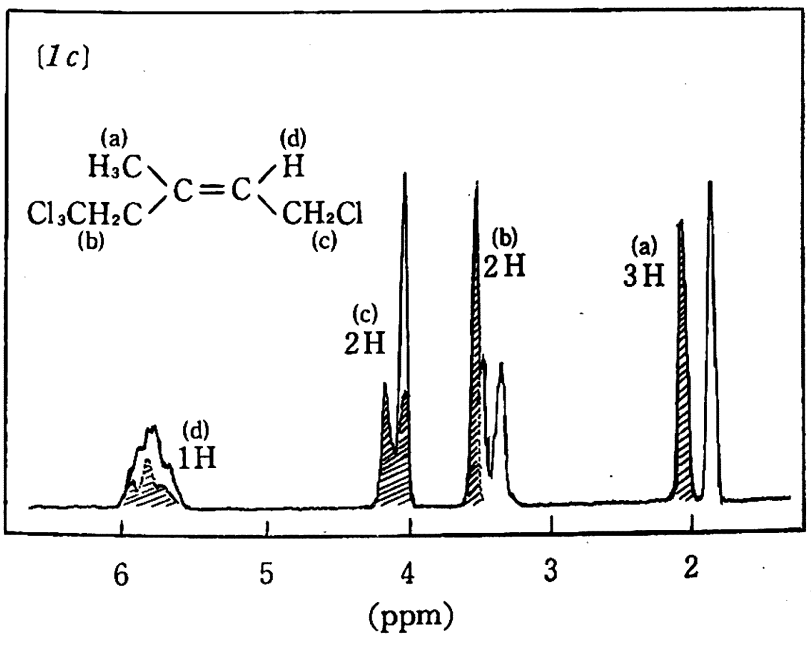

図 4 ピーク 2 と 3 の混合物 (II, II)の $\mathrm{NMR}^{* ?}$ （斜線の部分がピーク 2 のスペクトル）

3.2.4 IV(ピーク 4)の構造: ピーク 4 の分取物 IV N NMR は 因 5 に示すように，II（ピーク 2) と同様なパターンを示すことか ら， IV は I と同じ平面構造式〔2】を満足する。

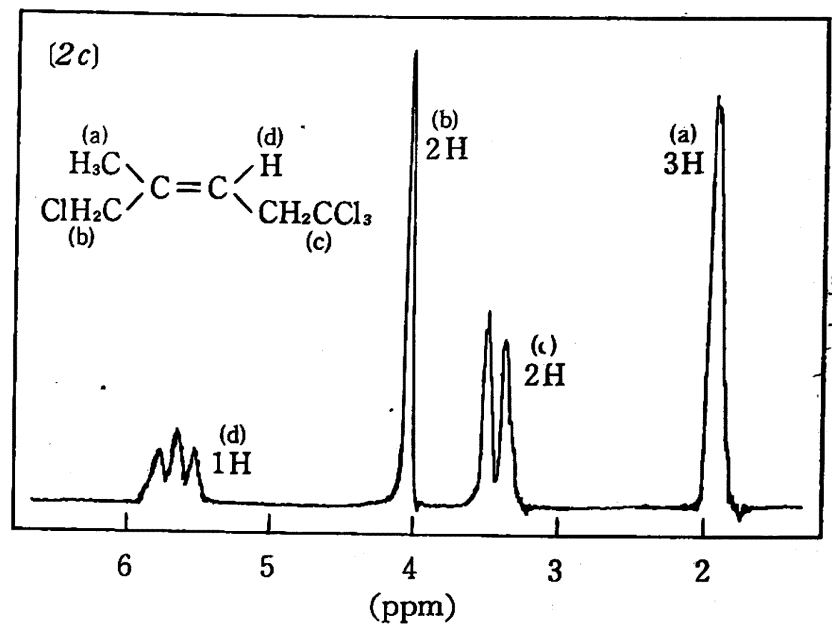

図 5 ピーク $4(\mathbb{I})$ の NMR*?

\section{3 立体構造}

上述の分析結果から， I (ピーク 1)と I I (ピーク 3)は 1,4-付

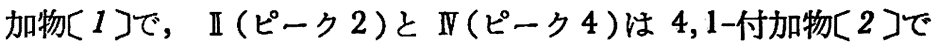
あり，それぞれ立体異性体であると考えられる。

この反応と類似した反応であるブタジェンとトリクロルブロム メタンとの放射線による反応に颃いて，その主生成物は，IR お よびラマンスペクトルから，1,4-トランス付加物であると報告さ れている13。これらの結果から I とI は，それぞれ 1,4-と 4,1付加物のトランス体であり，III IV がそれぞれ 1,4- と 4,1-付 加物のシス体であると考えられる。

さらに NMR において，アリルプロトンの遠隔カップリング に関しては， $J_{\text {cis }}$ の方が $J_{\text {trans }}$ よりもわずかに大きく通常 0.5 cps 程度の差異があり，カップリング定数は 0〜3 cps にあると

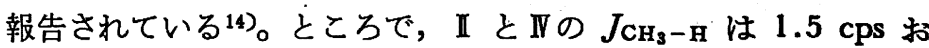

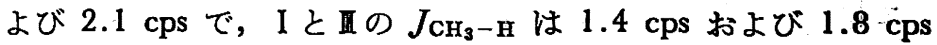
であり，Iと IVの方が対応した I とII J $\mathrm{J}_{\mathrm{CH}_{3}-\mathrm{H}}$ 值より大きな值 を示した。この結果から，I とII はトランス体であり，I と IIは シス体であることが推定される!

またこれらのピークの化学シフトに関して, I, 更および正， ザにおけるメチル基の化学シフトの差は, それぞれ 0.11 および $0.1 \mathrm{ppm}$ を示し，且およびNの方が低磁場側に吸収が見られた。 この結果は，cis-および trans-クロトン酸メチルなどの化学シフ トと同様な関係にあり，メチル基に対して電子吸引基がトランス 位にあり，シス位の場合よりも，より強く $\pi$ 電子を通しての反磁 性効果が起こっていることを示すものと考えられる15)。なおメチ ンプロトンの化学シフトに関しては， $\Delta_{\mathrm{I}-\mathrm{III}}=-0.08, \Delta_{\mathrm{II}-\mathrm{IV}=}$ $0.16 \mathrm{ppm}$ となり，I と吕に関しては上述と同様な現象と考えら れる。しかし II と $\mathbb{V}$ の場合には，塩化アリルによる空間的な反磁 性効果がシス位のメチン基に対して強く現われているものと考え られる16)。

以上の結果から， I， I， II， IV はとれぞれのシスートランス

13) G. S. H. Ghen, R. F. Stamm, J. Org. Chem., 28, 1580 (1963).

14) S. Sternhell, Rev. Pure Appl. Chem., 14, 15(1964).

15) R. R. Fraser, D. F. McGreer, Can. J. Chem., 30, 505(1961).

16) E. B. Whipple, J. H. Goldstein, L. Mandel, J. Am. Chem. Soc., 82, 3010(1960). 
立体異性体の関係にあり，構造 $[1 t] ，\left[\begin{array}{ll}1 & c\end{array}\right],[2 t],[2 c] を も$ つことが支持される。

\section{4 生成物に関する考察}

著者らと同系のレドックス触媒を用いた Afanasév らの)の研究 によれば， $n=1$ テロマ一生成物は GLG より 4 成分からなり， それらの生成割合から，イソプレンとトリクロルブロムメタンと の反応生成物 [1 $\left.1^{\prime}\right],\left[2^{\prime}\right],\left[3^{\prime}\right],\left[4^{\prime}\right]$ 刘応した構造式 $[1],[2]$, 〔3]，〔4〕をむつものであろうと推定されている。しかし著者ら の実験結果によれば，それとは反応条件，GLG 条件が異なって

\begin{tabular}{|c|c|}
\hline 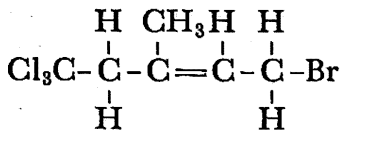 & 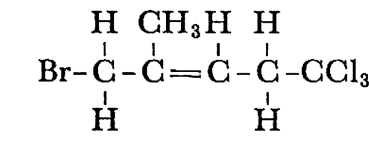 \\
\hline$\left[1^{\prime}\right]$ & {$\left[2^{\prime}\right]$} \\
\hline 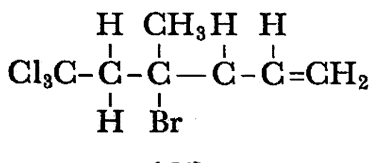 & 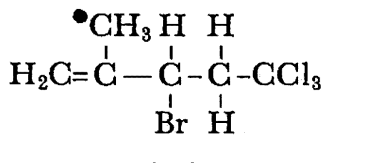 \\
\hline$\left[3^{\prime}\right]$ & {$\left[4^{\prime}\right]$} \\
\hline
\end{tabular}

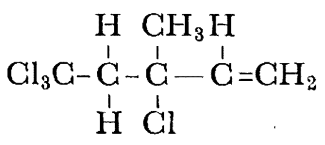

$1,2-$ 付加物 $[3]$<smiles>C=C(C)[C@H](Cl)[C@H](Cl)C(Cl)(Cl)Cl</smiles>

4,3-付加物[4]
はいるが，GLG における四つの主成分の構造は，〔1]および〔2】 で示さ机る 1,4-および 4,1-付加物のシスートランス異性体 $\left[\begin{array}{ll}1 & c\end{array}\right]$,

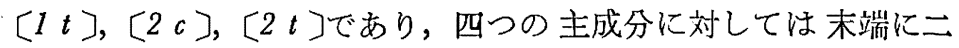
重結合を有する[3]，〔4]化合物は認められなかった。これら 〔3〕，〔4〕化合物に対しては，ピーク 5，6 付近を GLG 分取し， 混合物のままNMR を測定したところ，オレフィンプロトン領域 にビニル基特有の $\mathrm{ABX}$ パターンおよび末端メチレン基特有の $\mathrm{A}_{2}$ パターンの吸収が見られることから，ピーク $5 ， 6$ が[3]，〔4] に相当するものと推定される。これら[3]，〔4]の生成がほとん ど見られなかったことは，かさ高いトリクロルメチル基のために， 立体的にもまた電子諭的にも，これらの生成はかなり困難である ものと考えられる。

(1968 年 4 月, 日本化学会第 21 年会; 1968 年 10 月, 第 12 回 香料,テルペンおよび精油化学討論会典演)

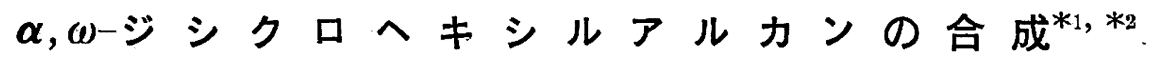

（昭 和 44 年 2 月 20 日受理）

石 沢 昭 雄*3 $\cdot$ 山村 正美*4. 後 藤 良 造*3

長鎖状化合物の合成と物性とに関する研究の一環として，長鎖状化合物の物性とその鎖長，および鎖末端の椿造との相関につい て検討を行ならために， $\alpha, \omega$-ジシクロへキシルフルカン $\langle\overrightarrow{\mathrm{H}}\rangle-\left(\mathrm{CH}_{2}\right)_{n}-\langle\overline{\mathrm{H}}\rangle$ の合成を行ない, $n=15 \sim 24$ の 10 種類の炭 化水素をえた。 $\omega$-フェニルフルキルカドミウムと $\omega$-フェニル脂肪酸塩化物との反応でケトン〈 を合成し，これを Huang-Minlon 法で還元してジフェニルアルカン<smiles>c1ccccc1</smiles>
$\left(\mathrm{CH}_{2}\right)_{m+n}$ とし，さらに酸化白金触媒の存 在下で常压水素化することによって相当するジシクロへキシルアルカンをえた。えられたジシクロへキシルフルカンおよび中間体 としてえられ夫ケトン，ジフェニルフルカンはすべて現在まで報告されていない新化合物である。

ジシクロヘキシルアルカンおよびジフェニルフルカンはともにその炭甞鎖長の奇数偶数変化にともなって融点は明瞭に交互する 現象を示した。

\section{1 緒言}

天然物からの分離，精製によってえられる長鎖状化合物は，同 族体などの不純物が混入する可能性から免れ難いため，純粋な出 発物質を用いて合成的にこれら長鎖状化合物を高純度でえようと する努力がなされ，同時にこれら高純度の化合物を用いて，融点， 融解(結晶化)熱, 比熱, 密度, 相転移現象などと結晶構造との相 関について検討がなされてきた。ことに鎖長と物性との関係につ いての検討は広範に行なわれ，これら長鎖状化合物の物性が結晶

*1との報文を“長鎖状化合物の合成と物性(節 11 報)” する。

*2 前報(第 10 報), A. Watanabe, A. Ishizawa, H. Takasaka, R. Goto, Bull. Chem. Soc. Japan, 42, 1360(1969).

*3 Akio IshizAwA, Ryozo Goto 京都大学理学部化学教 室, 京都市左京区北白川追分町

*4 Masami YAMAMURA 現在 丸善石油株式会社中央研究 所，和歌山県海草郡下津町
格子内における鎖状分子の排列に基づいて理解されることが明ら かにされてきた。しかし検討の対象とされてきた化合物は，ほと んど $n$ ーパラフィンあるいはその末端位のメチル基を 1 個だけ $\mathrm{CO}_{2} \mathrm{R}\left(\mathrm{R}=\mathrm{H}, \mathrm{CH}_{3}, \mathrm{C}_{2} \mathrm{H}_{5}\right), \mathrm{OH}$ ，八ロゲンで置換したものであ り，鎖末端位:置にかさだかい置掺基をるつような長鎖状化合物を 用いて，物性と鎖末端裂造との相関を検討した研究はほとえどな い。このような点についての検討を行なう目的で，鎖状化合物の 末端位置をシクロヘキシル基で置換した一連の化合物が合成され てきた1)。本報では鎖の両末端位置をシクロヘキシル基で置換し た $\alpha, \omega$-ジシクロヘキシルアルカン 〈 合成を報告する。

1） a ) 後藤良造, 石沢昭雄, 山村正美，日化, 88, 678(1967).

b) 石沢昭雄, 山村正美,一居誠, 阪下好顕, 後藤良 造, 日化，89，516(1968)。

c）石沢昭雄，山村正美，後藤良造，日化，89，815 (1968). 